\title{
Responsibility of PPAT for Differences in Transaction Value with Written Price
}

\author{
Acika Permatasari ${ }^{*}$, Gunarto ${ }^{* *}$, and Widhi Handoko**) \\ *) Faculty of Law, Universitas Islam Sultan Agung (UNISSULA) Semarang, E-mail: \\ acikapermatsari@gmail.com
}

*) Faculty of Law, Universitas Islam Sultan Agung (UNISSULA) Semarang, E-mail: gunarto@unissula.ac.id

${ }^{* *)}$ Faculty of Law, Universitas Islam Sultan Agung (UNISSULA) Semarang, E-mail: widhihandoko@unissula.ac.id

\begin{abstract}
This study aims to analyze the factors/reasons, legal consequences and PPAT's responsibility for the difference between the transaction value and the price written on the sale and purchase agreement. This research is included in sociological juridical research with descriptive analysis research specifications. Sources of data used are primary data and secondary data. The data collection was carried out by field research and library research, then after the data was analyzed, conclusions were drawn using qualitative methods. Based on the results of the study, it was found that there was a difference in the transaction value in the sale and purchase deed with the price written on the sale and purchase binding deed, namely the parties avoided high taxes. The legal consequences of PPAT related to the difference in transaction value are that the deed is null and void, the deed is degraded to a private deed and can be dishonorably dismissed from its position. PPAT responsibilities related to deeds include administrative responsibility, civil liability, and criminal responsibility.
\end{abstract}

Keywords: Sale; Purchase; Transaction; Price. 


\section{Introduction}

The transfer of land rights is a process of changing the former land rights holders to the current land rights holders. The transfer of land rights has two types of transfer of land rights, namely transfer and transfer. Switch shows the changing of land rights without any legal action being carried out by the owner.

Through Government Regulation Number 24 of 1997 concerning Land Registration Article 37 paragraph (1) which states that the transfer of land rights and ownership rights to apartment units through buying and selling, exchanging, grants, company data entry and other legal acts of transfer of rights, except Transfer of rights through auction can only be registered if it is proven by a deed made by the authorized PPAT according to the provisions of the applicable laws and regulations.

In the event that a sale and purchase whose object is an immovable object (fixed object), cannot be completed after the parties have paid and submitted the object only, the parties will make a deed of binding sale and purchase to a notary as a form of realization of the transfer of rights between them legally, which aims to protect their respective rights from all risks of ownership of the object of sale and purchase in the future.

As it is known that a person who owns property basically gives the owner the authority over power in addition to the obligation to take action or deed on the object that belongs to him. The aspect of land legality is very important for proof of ownership of land to provide certainty to the parties that there is a legal owner of the land. ${ }^{1}$

Land registration is carried out to ensure legal certainty of land rights as mandated in Article 19 of Act No. 5 of 1960 concerning Agrarian Principles that the government is obliged to carry out land registration throughout Indonesia and requires land rights holders to register. ${ }^{2}$

The Land Deed Official Deed is one of the main sources in the context of maintaining land registration data, so the main tasks of the Land Deed Maker Official (PPAT) and how to implement it are also regulated in the Government

\footnotetext{
${ }^{1}$ L\&J A Law Firm, Kiat dan Prosedur Mengurus Dokumen Tanah dan Bangunan, (Jakarta: Nera Pustaka, 2013), p.7.

${ }^{2}$ Kurniawan Ghazali, Cara Mudah Mengurus Sertifikat Tanah, (Jakarta: Kata Pena, 2013), p.65. 
Regulation. The Land Deed Maker Official (PPAT) is required to submit the land deed he made along with the relevant documents to the Land Office for registration purposes. ${ }^{3}$

A PPAT in making a deed of sale and purchase must ensure that all the conditions in the buying and selling process as well as the requirements for making the deed have been met so as not to trigger a dispute or conflict between the parties who feel aggrieved by the existence of the deed.

In accordance with the conditions for the validity of an agreement according to the formulation of Article 1320 of the Civil Code, if one or more of the conditions for the validity of the contract are not fulfilled, it can bring juridical consequences, namely null and void (nietig, null and void) and can be canceled (vernietigbaar, voidable) ${ }^{4}$

Before making the Sale and Purchase Deed, if the requirements have not been met, then the parties can bind themselves by binding the sale and purchase at a notary. In the deed of binding sale and purchase, it is specifically described, namely the agreement of the parties, obligations, objects sold and the sale and purchase price that has been agreed upon by both parties, namely the seller and the buyer.

In the process of buying and selling land, the seller and buyer of course will be subject to tax. The parties/clients put an untrue transaction price in the Deed of Sale and Purchase (AJB) made by the Land Deed Making Official (PPAT) so that they can pay taxes, both the payment of Land Rights Acquisition Duty (BPHTB) and Income Tax (PPh) with a tax value the lowest possible. This seems to manipulate the transaction price listed in the deed of sale and purchase, even though the reported price will be used as the basis for calculating PPh and BPHTB.

The author wants to analyze more deeply the factors that cause differences in the transaction value in the Sale and Purchase Deed with the transaction price in the Sale and Purchase Binding Deed, PPAT's responsibilities and legal consequences related to the difference in the transaction value in the Sale

\footnotetext{
3 Luluk Lusiati Cahyarini dan Widhi Handoko, Rekonstruksi Sistem Pendaftaran Tanah, Menuju Terciptanya Sistem Pra-Pendaftaran Tanah di Tigkat Desa/Kelurahan Berbasis Nilai Keadilan Sosial, (Semarang: Unissula Press, 2020), p.91.

${ }^{4}$ Abdulkadir Muhammad, Hukum Perdata Indonesia, (Bandung: PT Citra Aditya Bakti, 2000), p.233.
} 
and Purchase Deed with the transaction price in the Sale and Purchase Binding Deed.

\section{Research Methods}

To examine the problems above, the type of research used in writing this thesis is sociological juridical research. Data collection was carried out by field research and library research, then after the data was analyzed, conclusions were drawn using qualitative methods.

\section{Result and Discussion}

Factors that cause differences in the transaction value in the Sale and Purchase Deed (AJB) with the price written on the Sale and Purchase Binding Deed (PJB)

\subsection{Position Case}

In this case, the author makes observations on the PPAT " $X$ " notary, where the clients (sellers and buyers) ask PPAT " $X$ " to include the sale and purchase transaction value lower than the price written on the sale and purchase binding deed. The notary who makes the deed of binding sale and purchase and the PPAT who makes the deed of sale and purchase are the same person, namely the notary PPAT " $X$ ".

In the deed of sale and purchase it is written "This sale and purchase is carried out at a price of IDR 3,000,000,000, - (Three billion rupiahs)", while in the deed of binding sale and purchase agreement it is written in Article 2 that the sale and purchase will be carried out and accepted by the parties with the price of IDR 6,225,000,000, - (six billion two hundred and twenty five million rupiah).

This states that there is a difference between the transaction value in the deed of sale and the price written on the deed of sale and purchase engagement. A PPAT Notary who makes a sale and purchase deed with a transaction value that is not the same as the price written on the Sale and Purchase Binding Deed is a violation and has legal consequences. 


\subsection{Legal Certainty Theory}

Certainty is a word that comes from certain, which means of course, it is fixed, it can't be no, something that is certain. A German legal philosopher named Gustav Radbruch teaches that there are three basic legal ideas, which most legal theorists and legal philosophers identify as three legal goals, including justice, expediency and legal certainty. ${ }^{5}$

The price of the sale and purchase transaction is the certainty of value in tax calculations. In relation to article 1320 of the Civil Code, the transaction price is included in the legal terms of the agreement point of a certain matter and the causes that are lawful or not prohibited. Certainty provides clarity in carrying out legal actions when implementing an agreement. Article 1335 of the Civil Code explains that an agreement without a cause, or has been made for a false or forbidden cause, has no legal force.

The value of legal certainty provides clarity in carrying out legal actions during the implementation of a sale and purchase agreement and clear sanctions so that the agreement must be carried out in accordance with applicable law and does not conflict with laws and regulations, morality and public order, both for PPAT notaries who are authorized to make authentic deeds, sellers and buyers.

\subsection{Research result}

The factor/reason for the difference in the transaction value on the sale and purchase deed with the price written on the sale and purchase binding deed is that the parties (seller and buyer) avoid high taxes so that the parties want to include a lower transaction value than the actual price. This is also an obstacle in the implementation of the BPHTB tax in relation to buying and selling. ${ }^{6}$

According to the author's observations, the overall factor is avoiding high taxes, there are several other factors that cause differences in the

\footnotetext{
${ }^{5}$ Achmad Ali, Menguak Teori Hukum (Legal Theory) \& Teori Peradilan (Judicialprudence) Termasuk Undang-Undang (Legisprudence) Volume I Pemahaman Awal, (Jakarta: Kencana Prenada Media Group, 2010), p.288.

${ }^{6}$ Interview with Ms. Ferra, BPHTB verification division, Semarang City Bapenda, July 15, 2021 at 11:30 WIB.
} 
transaction value in the sale and purchase deed with the price written on the sale and purchase binding deed, namely:

\section{Proximity between Notary/PPAT and client}

A Notary/PPAT with clients who know each other well, where they believe they will protect each other and will not reveal the secrets that exist between them. This creates confidence among them that the actions that have been carried out are safe and there will be no problems in the future.

\section{Client request}

The parties/clients include the actual transaction price in the sale and purchase binding deed (PJB). However, in the sale and purchase deed (AJB), the parties ask PPAT to include a transaction value that is not the same as the price written on the sale and purchase binding deed.

In the implementation of the registration of the transfer of land rights must meet one of the conditions, namely the payment of taxes. In paying the BPHTB tax, if there is suspicion about the value of the sale and purchase transaction, Bapenda will check the location of the object of the sale and purchase. Bapenda asks for proof of payment and if it can't prove it then it is subject to tax underpayment, in which the tax is adjusted to the transaction price that has been set by Bapenda after checking the location. ${ }^{7}$ In accordance with Article 12 paragraph (2) letter $b$ of the Regional Regulation of Semarang City Number 2 of 2011 explains the SKPDKBT if new data is found and/or previously undisclosed data causes an increase in the amount of tax payable.

\section{Unhealthy competition between fellow Notaries/PPAT}

The increasing number of notaries/PPATs will trigger competition among fellow notaries/PPATs. According to research, PPAT follows the will of the parties in the inclusion of the transaction value in the deed of sale and purchase it makes. This is done to get a good relationship with the relation or friend, because if the PPAT concerned does not want to fulfill the wishes of the parties, the client can switch to another PPAT.

\footnotetext{
${ }^{7}$ Ibid.
} 
The legal consequences and liability of PPAT related to the difference in the value of the transaction in the Sale and Purchase Deed (AJB) with the price written on the Sale and Purchase Binding Deed (PJB)

\subsection{Use of Causality Theory (Adequate)}

The teaching of causality aims to determine the relationship between cause and effect. An event that occurs is always preceded by a series of actions (deeds) that end with the realization of the event, as well as criminal events (criminal acts). Which action from a series of actions is the cause of the realization of a crime, is the focus of the teaching of causality. ${ }^{8}$ Causality theory can be divided into 4 things, namely individualized causality, generalized causality, subjective adequate causality, and objective causality. ${ }^{9}$

According to E. Utrech, proposed by J. Von Kries, the subjective adequate theory explains that the cause is an act whose consequences can be known/predicted by the perpetrator. ${ }^{10}$ Adam Chazawi explained that inner attitude is in the form of knowledge (awareness) that the action to be carried out is adequate to cause consequences and this feasibility must be based on human experience in general. ${ }^{11}$

Related to the research, that a notary/PPAT who has the authority to make an authentic deed but does not meet the legal requirements of the agreement and violates the applicable regulations is aware that the actions taken will have legal consequences. PPAT includes participating in entering false information on authentic deeds (Article 266 of the Criminal Code). It is proven that he intentionally (with full awareness) took legal action which he knew was an unlawful act.

\subsection{Research result}

a. The legal consequences related to the difference in the transaction value in the sale and purchase deed with the price written on the sale and purchase binding deed.

\footnotetext{
${ }^{8}$ Ahmad Sofian, Ajaran Kausalitas Hukum Pidana, (Jakarta: Prenadamedia group, 2018), p.101.

${ }^{9}$ M.Syarifudin Abdillah, PENERAPAN ASAS KAUSALITAS DALAM KECELAKAAN LALU LINTAS YANG MENYEBABKAN KORBAN MENINGGAL DUNIA, Jurnal kertha Semaya, Vol.8/No.5/Tahun 2020, p.803, https://ojs.unud.ac.id/index.php/kerthasemaya/article/download/58876/35109/, Accessed on July 7, 2021 at 21.16 WIB.

10 Utrecht, Asas-asas Hukum Pidana, (jakarta: Rineka Cipta, 1994), p.386.

${ }^{11}$ Adami Chazawi, Pelajaran Hukum Pidana, (Jakarta: Raja Grafindo Persada, 2001), p.223.
} 
According to the researcher, the value of the sale and purchase transaction is included in the legal terms of the 3 (three) and 4 (four) points of the agreement, namely a certain thing and the causes that are lawful or not prohibited. Based on Article 1335 of the Civil Code explains that an agreement without a cause, or one that has been made for a false or forbidden cause, has no power. Article 1337 of the Civil Code only states that a reason is prohibited, if it is prohibited by law, or if it is against good decency or public order.

One of the legal conditions of the agreement is not fulfilled, causing the agreement to be invalid. The legal consequences of the PPAT deed that do not meet the legal requirements of a lawful causal agreement (objective requirements) namely null and void means that from the start the agreement has been canceled, or is considered to have never existed. The agreement is null and void, from the beginning there has never been an agreement and there has never been an engagement.

Article 1869 of the Civil Code explains that a deed which because of the inability or incompetence of the employee referred to above or because of a defect in its form, cannot be treated as an authentic deed but nevertheless has the power as an underhand deed. This means that a deed does not have the strength of authentic evidence and only has the strength of evidence under the hand if:

Parties who experience losses can claim compensation and costs from PPAT by proving it in court in court, because the making of an authentic deed must contain three elements, namely external, formal and material or one of these elements is incorrect and can lead to a criminal or civil case.

b. PPAT's responsibility regarding the difference in the transaction value at AJB with the price written on the PJB Deed

1) Administrative responsibilities

The author is of the opinion that PPAT has violated Article 62 of Government Regulation Number 24 of 1997 concerning land registration and has violated the PPAT code of ethics in the form of violating the provisions of the law related to PPAT's main duties in accordance with Article (4) letter $r$ of the IPPAT code of ethics dated 27 April 2017 and members who violate the code ethics may be subject to sanctions in the form of: (Article 6 of the PPAT Code of Ethics) 

a) reprimand;
b) warning;
c) schorsing (temporary dismissal) from membership of IPPAT associations;
d) onzetting (dismissal) from membership of IPPAT associations;

e) dishonorable discharge from membership of the IPPAT association.

\section{2) Civil liability}

The determination that the deed is degraded into an underhand deed or declared null and void and/or null and void by law, and becomes an offense against the law that causes losses, must be based on the existence of a court decision that has permanent legal force. The party who accuses or judges that the PPAT deed is correct because there has been a deviation from the material or formal requirements of the procedure for making the PPAT deed, then the party must prove the accusation or self-assessment through a civil lawsuit legal process.

3) Criminal liability

Violation of Article 266 paragraph (1) of the Criminal Code can only be suspected of PPAT when it finds out that the information requested by the parties to be included in the deed is not true but PPAT is still willing to make the deed, then PPAT in this case can be charged with committing a crime Article 266 paragraph (1) KUHP Jo. Article 56 paragraph (1) of the Criminal Code, with the maximum penalty that can be imposed for an act of assisting a crime Article 266 paragraph (1) of the Criminal Code.

\section{Closing}

There are various factors/reasons that cause the making of the deed of sale and purchase by the PPAT not in accordance with the procedure for making the deed of the PPAT, one of which is the difference in the value of the transaction in the deed of sale and purchase with the price written on the deed of binding sale and purchase. Factors/reasons for the difference in transaction value between AJB and PJB are the closeness between the notary/PPAT and the client, client 
requests, unhealthy competition between fellow notaries/PPAT. And the legal consequences of PPAT related to the difference in the value of the transaction in the deed of sale and purchase with the price written on the deed of binding sale and purchase are that they can be dishonorably dismissed from their position for providing incorrect information in the deed, the deed has been degraded into an underhand deed, the agreement has been canceled or deemed to be there never was. Responsibilities of notaries and PPATs as public officials include PPAT's professional responsibilities related to deeds including administrative responsibilities, civil responsibilities, and criminal responsibilities.

\section{References}

Journals:

[1] Dewi Kurnia Putri, PERBEDAAN PERJANJIAN PENGIKATAN JUAL BELI LUNAS DENGAN PERJANJIAN PENGIKATAN JUAL BELI TIDAK LUNAS, Jurnal Akta, Vol.4/No.4/dec/2017, http://jurnal.unissula.ac.id/index.php/akta/article/view/2505

[2] Indah Sari, PERBUATAN MELAWAN HUKUM (PMH) DALAM HUKUM PIDANA DAN HUKUM PERDATA, Jurnal IImiah Hukum Dirgantara-Fakultas Hukum Universitas Marsekal Suryadarma, Vol.11/No.1/September/2020, hal.54,

https://journal.universitassuryadarma.ac.id/index.php/jihd/article/view/ $651 / 622$

[3] M.Syarifudin Abdillah, PENERAPAN ASAS KAUSALITAS DALAM KECELAKAAN LALU LINTAS YANG MENYEBABKAN KORBAN MENINGGAL DUNIA, Jurnal kertha Semaya, Vol.8/No.5/Tahun 2020, p. 803,. https://ojs.unud.ac.id/index.php/kerthasemaya/article/download/58876/ 35109/

[4] Mahmud Mulyadi Hamdan, TINDAK PIDANA MENYURUH MEMASUKKAN KETERANGAN PALSU DALAM AKTE OTENTIK (STUDI PUTUSAN NOMOR 1545/PID.B/2012 PN. MEDAN. JO PUTUSAN NOMOR: 39/PID/2013/PT.MEDAN.), USU Law Journal, Vol.3/No.3/November/2015, p.102, https://media.neliti.com/media/publications/14285-ID-tindakpidana-menyuruh-memasukkan-keterangan-palsu-dalam-akte-otentikstudi-putu.pdf 
Books:

[1] Ali, Ahmad, Menguak Tabir Hukum (Suatu Kajian Filosofis dan Sosiologis), (Jakarta: Toko Gunung Agung, 2002)

[2] Ashshofa, Burhan, Metode Penelitian, (Semarang: Media Press, 2007)

[3] Barkatullah, Abdul Halim dan Teguh Prasetyo, Bisnis E-commerce Studi Sistem Keamanan dan Hukum di Indonesia, (Yogyakarta: Pustaka Belajar, 2005)

[4] Cahyarini, Luluk Lusiati dan Widhi Handoko, Rekonstruksi Sistem Pendaftaran Tanah, Menuju Terciptanya Sistem Pra-Pendaftaran Tanah di Tigkat Desa/Kelurahan Berbasis Nilai Keadilan Sosial, (Semarang: Unissula Press, 2020)

[5] Chazawi, Adami, Pelajaran Hukum Pidana, (Jakarta: Raja Grafindo Persada, 2001)

[6] Ghazali, Kurniawan, Cara Mudah Mengurus Sertifikat Tanah, (Jakarta: Kata Pena, 2013)

[7] L\&J A Law Firm, Kiat dan Prosedur Mengurus Dokumen Tanah dan Bangunan, (Jakarta: Nera Pustaka, 2013)

[8] Lubis, M.Solly , Filsafat Ilmu dan Penelitian, (Bandung:Mandar Maju, 1994)

[9] Mahasari, Jamaluddin, Pertanahan dalam Hukum Islam, (Yogyakarta: Gama Media, 2008)

[10] Muhamad Abdul Kadir, Hukum Perdata Indonesia, (Bandung: PT Citra Aditya Bakti, 2000)

[11] Utrecht, Asas-Asas Hukum Pidana, (Jakarta: Rineka Cipta, 1994)

Regulations:

[1] Act No. 2 of 2014 concerning Amendments to Act No. 30 of 2004 concerning the Position of Notary 
[2] Act No. 5 of 1960 concerning Basic Agrarian Laws

[3] Code of Civil law

[4] Constitution 1945

[5] Government Regulation of the Republic of Indonesia Number 24 of 1997 concerning Land Registration

[6] Government Regulation of the Republic of Indonesia Number 24 of 2016 concerning Amendments to Government Regulation Number 37 of 1998 concerning Position Regulations for Land Deed Maker Officials

[7] Government Regulation of the Republic of Indonesia Number 34 of 2016 concerning Income Tax on Income from the Transfer of Rights to Land and/or Buildings, and Sale and Purchase Agreements on Land and/or Buildings and their Amendments

[8] Semarang City Regional Regulation No. 2 of 2011 concerning Fees for Acquisition of Land and Building Rights

Internet:

[1] Rahmad Hendra, Tangung Jawab Notaris Terhadap Akta Otentik Yang Penghadapnya Mempergunakan Identitas Palsu Di Kota Pekanbaru, https://media.neliti.com/media/publications/9131-ID-tanggungjawabnotaris-terhadap-akta-otentik-yang-penghadapnya-mempergunakaniden.pdf

[2] Sedyo Prayogo, Penerapan Batas-Batas Wanprestasi Dan Perbuatan Melawan Hukum Dalam Perjanjian, https://core.ac.uk/download/pdf/236376791.pdf 